\title{
The Clinical Course of Rheumatoid Arthritis in Kazakhstani Patients
}

\author{
Argul Issilbayeva ${ }^{1,2 *}$ (D), Assel Meiramova, ${ }^{1,2}$, Almagul R. Kushugulova ${ }^{1}$, Zhanar B. Akhmetova ${ }^{1,3}$, Damir Biktashev ${ }^{2}$, \\ Baglan B. Abdakhina ${ }^{2}$, Aliya T. Aituganova ${ }^{2}$, Yekaterina Zueva ${ }^{4}$, Karina Karlygash ${ }^{2}$ (D), Bayan A. Ainabekova ${ }^{2}$ \\ ${ }^{1}$ Laboratory of Human Microbiome and Longevity, Center for Life Sciences, National Laboratory Astana, Nazarbayev \\ University, Nur-Sultan, Kazakhstan; ${ }^{2}$ Department of Internal Medicine with the Course of Gastroenterology, Endocrinology \\ and Pulmonology, NJSC Astana Medical University, Nur-Sultan, Kazakhstan; ${ }^{3}$ Department of Internal Medicine with Geriatrics \\ course, NJSC Astana Medical University, Nur-Sultan, Kazakhstan; ${ }^{4}$ Department of Molecular Biology, Ariel University, Medical \\ Faculty, Ashkelon, Israel
}

Edited by: Ksenija Bogoeva-Kostovska Citation: Issilbayeva A, Meiramova A, Kushugulova AR, Akhmetova ZB, Biktashev D, Abdakhina BB, Aituganov AT, Zueva Y, Karlygash K, Ainabekova BA. The Clinica
Course of Rheumatoid Arthritis in Kazakhstani Patients. Course of Rheumatoid Arthritis in Kazaknstani Patients
OpenAccess Maced JMed Sci. 2021 Nov 10; 9 (B): 1352-1358

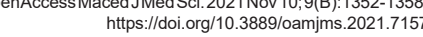
Keywords: Anti-citrullinated protein/peptide antibody; Clinic; Rheumatoid arthritis; Rheumatoid factor; Seropositive; Seronegative; Kazakhstan *Correspondence: Argul Issilbayeva, Laboratory of Human Microbiome and Longevity, Center for Life Sciences, Sultan Laboratory Astana, Nazarbayev University, NurSultan, Kazakhsan. E-mail: isilbayeva.a@gmail.com Received: 27 -Aug-202 Revised: 10-Oct-2021
Accepted: $31-O c t-2021$ Copyright: ๑ 2021 Argul Issilbayeva, Assel Meiramova, Almagul R. Kushugulova, Zhanar B. Akhmetova, Damir Biktashev, Baglan B. Abdakhina, Aliya T. Aituganova, katerina Zueva, Karina Karlygash, Bayan A. Ainabekova Funding: This study was supported by the Ministry of Education and Science of the Republic of Kazakhstan e grant AP08052703 "Determination of microbiomic Kazakhstan population Competing Interests: The authors have declared that no
competing interests exist
Open Access: This is an open-access article distributed Competing Interests: The authors have declared that no
competing interests exist
Open Access: This is an open-access article distributed Open Access: This is an open-access article distribute NonCommercial 4.0 International License (CC BY-NC 4.0)

\begin{abstract}
BACKGROUND: Rheumatoid arthritis (RA) prevalence according to the worldwide epidemiological data varies from $0.4 \%$ to $1.3 \%$. The disability and mortality rate in RA is high. RA clinic is various, and compiles from articular and
\end{abstract} systemic manifestations.

AIM: The aim of our study was to investigate the clinical course of RA in Kazakhstani patients living in North region of our country.

METHODS: The 81 women at the age of 30-55 years with a verified diagnosis of RA who have lived in Kazakhstan for at least 10 years were recruited to the study. All participants were examined by the rheumatologist and a standard laboratory examination was carried out. Statistical analysis was conducted in IBM SPSS Statistics 26 software (IBM. USA;1).

RESULTS: The statistically significant higher frequency of erosive radiological stages, bone ankylosis $\left(\chi^{2}=18.070\right.$ $\mathrm{df}=6 \mathrm{p}=0.005$ ) was found in seropositive (rheumatoid factor $[R F]+$ ) anti-citrullinated protein/peptide antibody positive (ACPA+) subgroup. The correlation analysis showed strong association between certain RA form activity and inflammatory markers, as well as disease triggers. The discriminant model which predicts the stage of radiological damage was obtained. The sensitivity of model in predicting X-ray Stage I-71.6\%, Stage II-29.4\%, Stage III-37.5\%, and Stage IV-63.6\%.

CONCLUSION: The debut of the RA on average occurred in the third decade of the patients' life. The joint syndrome had a more unfavorable character RF+ACPA+ patients' subgroup; however, RF+ACPA-negative (ACPA-) subgroup also showed a predisposition to poorer prognosis. The obtained discriminant model may be useful for RA patients management.

\section{Introduction}

Rheumatoid arthritis (RA) prevalence according to the worldwide epidemiological data varies from $0.4 \%$ to $1.3 \%$ [1], [2]. The women are more affected to this disease, especially in reproductive age [3], [4]. The ratio of female to male persons is 4:1 [5], [6].

The disability and mortality rate is high in patients withRAcomparedtogeneralpopulation[7],[8],[9].According to Sokka et al., there was increase in mortality rate of RA of 1, 5 times [9].

RAclinic is various, and compiles from articular and systemic manifestations. Synovitis, as main culprit, leads to articular destruction and early disability and even premature death. Any joint may be involved to pathological process, leading to the main RA clinical symptom as symmetric polyarthritis [10], which, in turn, leads to joint destruction and loss of working ability. Systematic manifestations such as rheumatoid nodules, serositis, vasculitis, neuropathy, eye lesions, and Sjogren's syndrome also contribute to the disease aggravation and worsen prognosis [11].

The specific autoantibody production, such as rheumatoid factor (RF) and anti-citrullinated protein/peptide antibody (ACPA), occupy one of the key niches in the disease development and contribute to disease severity. RF and ACPA positivity is associated with early bone destruction and development of RA complications [12], [13], and also contribute to activity increase by DAS28, X-ray stage progression, and low possibility of remission [14], [15].

Environmental and genetic factors play a key role in disease formation. Smoking significantly increases the risk of RA development and takes a dominant place in RA pathogenetic.

Smoking is the most studied environmental risk factor and it doubles risk of RA development [16]. There are several environmental factors include alcohol intake, Vitamin D intake, oral contraceptive use, high birth weight, breastfeeding duration, educational 
level, dietary habits, and even low socioeconomical status that potentially may play a particular role in RA development [16], [17], [18].

We initiated the study of RA clinic among Kazakhstani patients to obtain the data on peculiarities of disease course in our population.

\section{Methods}

The 81 women at the age of $30-55$ years with a verified diagnosis of RA who have lived in Kazakhstan for at least 10 years were recruited to the study. The study was conducted in accordance with the Helsinki Declaration and was approved by the local ethics committee of Nazarbayev University.

All women included in the study were examined by a rheumatologist in compliance with infectious safety measures in the context of the COVID-19 epidemic. The data were entered into the individual cards of the studied patients.

Collecting anamnesis of the disease, data on the onset of the disease were taken into account, including the nature of the lesion of the joint syndrome at the onset of the disease, the age of the patient at the time of RA manifestation, the duration of the disease, the subjective relationship of the disease with any endogenous or exogenous trigger, and the period from the onset of the disease to the diagnosis of RA.

The collection of clinical data was based on the results of an objective examination of patients by a rheumatologist, as well as by collecting complaints, anamnesis of the disease, and life mentioned earlier. Physical examination was carried out with the determination of the assessment of consciousness, examination of the skin, visible mucous membranes, palpation of peripheral lymph nodes, assessment of the state of muscle tissue, as well as anthropometric data, calculation of body mass index by the method of Ketle, measurement of blood pressure, heart rate, borderline personality disorder, and body temperature. The organs and systems were examined by palpation, percussion, and auscultation. The examination of the musculoskeletal system was carried out according to generally accepted rules. The tender joint count (TJC) and swollen (SJC) large and small joints count were obtained. The symptoms of transverse compression of the hands and feet, the strength of the compression of the hands were evaluated. The individual chart showed the involvement of the proximal and distal interphalangeal joints of the thumbs and other small joints with deformity and defiguration in the pathological process. Data on extra-articular manifestations of the disease and the development of complications were recorded. Pain was assessed by both the patient and the doctor using a visually analog pain scale (VAS), and the overall average score was analyzed. The disease activity was assessed according to the DAS28 disease activity index in RA. The X-ray stage was assessed according to the X-ray images for the last year. Functional status stratified according to ability to perform usual activities of daily living (self-care, professional and non-professional).

All patients underwent laboratory testing in the clinical and diagnostic laboratory. Blood sampling was carried out strictly on an empty stomach, after a 12-14 $\mathrm{h}$ period of fasting, in compliance with infectious safety measures. All patients underwent general clinical methods of research with the determination of indicators of the general blood test: The content of hemoglobin, red blood cells, platelets, leukocyte formula, and the erythrocyte sedimentation rate according to Panchenkov and Westergren; and the determination of the indicators of the general urinalysis. Biochemical blood tests determined the levels of alanine aminotransferase, aspartate aminotransferase, total protein, protein fractions, creatinine, cholesterol, glucose, and C-reactive protein (CRP). Immunological parameters such as RF, ACPA, antibodies to SS-A (Ro), and SS-B (La) components were also determined. ACPA and RF were measured with a second-generation enzyme-linked immunosorbent assay.

Statistical analysis of the data was carried out according to the generally accepted standards in the program IBM SPSS Statistics 26 software (IBM.USA; 1 ).

\section{Results}

The study group included 81 women diagnosed with RA aged 30-55 years, $\mathrm{Me}=43.98$ 95\% Cl (43-45).

About $75.3 \%(n=61)$ of the women studied had a seropositive (RF+) variant of the course of RA, while $24.3 \%(n=20)$ had a seronegative (RF-) one, while $70.7 \%(n=58)$ had an ACPA-positive (ACPA+) variant and $28 \%(n=23)$ ACPA-negative (ACPA-) variant of the disease course, in connection with which a comparative analysis was conducted between the $\mathrm{RF}+\mathrm{ACPA}+$, RF+ACPA-, and RF - ACPA+ subgroups (Table 1).

Table 1: Distribution of subjects in subgroups

\begin{tabular}{|c|c|c|c|c|c|c|}
\hline \multirow[t]{2}{*}{ Variables } & \multicolumn{2}{|c|}{$R F+A C P A+n=38$} & \multicolumn{2}{|c|}{ RF+ACPA-n=23 } & \multicolumn{2}{|c|}{ RF- $A C P A+n=20$} \\
\hline & $\mathrm{Me} / \mathrm{n}$ & Q1-Q3/\% & $\mathrm{Me} / \mathrm{n}$ & Q1-Q3/\% & $\mathrm{Me} / \mathrm{n}$ & Q1-Q3/\% \\
\hline $\mathrm{R}$ & 43.5 & $37.5-51$ & 44 & $31-50$ & 47 & $39-51$ \\
\hline Kazakh ethnic & 35 & $92.1 \%$ & 20 & $87 \%$ & 16 & $80 \%$ \\
\hline Slavic ethnic $g$ & 3 & $7.9 \%$ & 3 & $13 \%$ & 4 & $20 \%$ \\
\hline
\end{tabular}

The comparative analysis showed that the frequency of disease triggers had equal proportions both in the seropositive course of the disease and in the seronegative course.

The study of the disease debut in the studied subgroups showed no statistically significant differences. 
However, it should be noted that the median age of disease onset in the RF - ACPA+ group was 40.5 years, which is relatively higher than in the seropositive subgroups (Figure 1 for all indicators $p$ > 0.05).

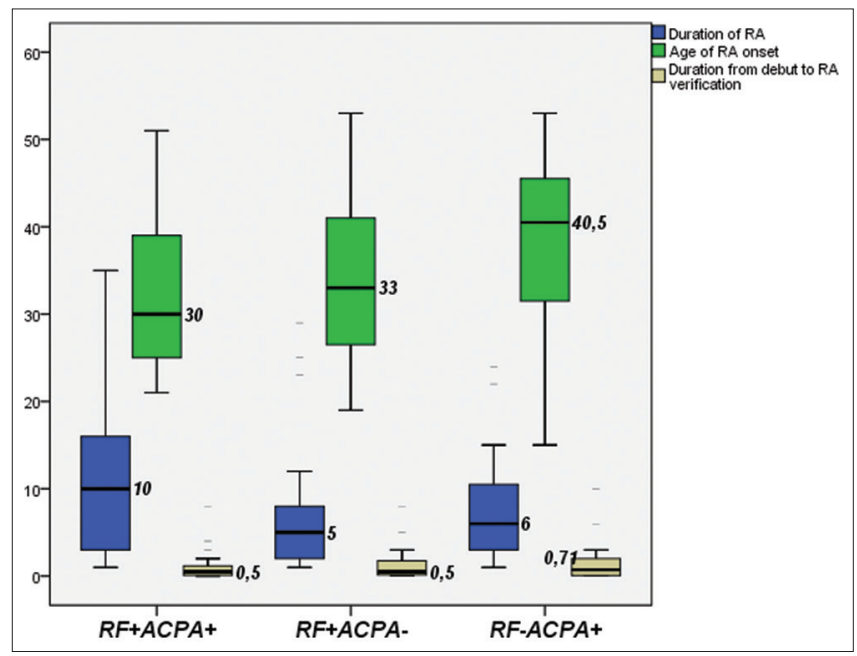

Figure 1: Comparative analysis of the disease debut in the studied subgroups

Further, a comparative analysis of the clinical course of the disease was carried out, which showed a predominance of the articular form in all the studied subgroups. At the same time, the proportion of symmetrical joint lesions did not differ statistically and accounted for $80.6 \%, 73.9 \%$, and $68,4 \%$, respectively, but women with $\mathrm{RF}+\mathrm{ACPA}+$ course of the disease had a significantly higher incidence of late-stage disease $39.5 \%, 8.7 \%$, and $5 \%$, respectively, $\chi^{2}=12.410 \mathrm{df}=2 \mathrm{p}=0.002$ (Table 2).

Table 2: Clinical data of RA in the studied subgroups

\begin{tabular}{|c|c|c|c|}
\hline \multirow[t]{2}{*}{ Variables } & $\mathrm{RF}+\mathrm{ACPA}+, \mathrm{n}=38$ & RF+ACPA-, $n=23$ & RF-ACPA+, $n=20$ \\
\hline & \multicolumn{3}{|l|}{$\mathrm{n}(\%) / \mathrm{Me}(\mathrm{Q} 1-\mathrm{Q} 3)$} \\
\hline Expanded stage of RA & $23(60.5 \%)$ & $21(91.3 \%)$ & $19(95 \%)$ \\
\hline Late stage of RA & $15(39.5 \%)$ & $2(8.14 \%)$ & $1(5 \%)$ \\
\hline Joint syndrome & $38(100 \%)$ & $22(95.7 \%)$ & $19(95 \%)$ \\
\hline Symmetrical arthritis & $29(80.6 \%)$ & $17(73.9 \%)$ & $13(68.4 \%)$ \\
\hline Asymmetrical arthritis & $9(19.4 \%)$ & $6(26.1 \%)$ & $7(31.6 \%)$ \\
\hline TJC & $7(2-4.5)$ & $6(2-13)$ & $7(4-13.5)$ \\
\hline SJC & $3(1-9.5)$ & $2(0-8)$ & $2.5(0-5.75)$ \\
\hline VAS & $5(3-7)$ & $5(3-7)$ & $5(3-7)$ \\
\hline DAS28 & $4.59(3.8-6.2)$ & $4.5(3.7-5.4)$ & $4.28(3.2-5.6)$ \\
\hline Disease activity & $2(2-3)$ & $2(2-3)$ & $2(2-3)$ \\
\hline
\end{tabular}

The comparative analysis of the disease activity in terms of TJC, SJC, VAS, and DAS 28 also showed no statistically significant differences (Table 2; for all indicators $p>0.05)$, thus the course of the disease among the studied individuals with the seropositive form did not have such clinical differences with the seronegative form of the disease, which was reflected in the frequency of involvement in the pathological process of large and small joints (Figure 2).

However, a profound study of the joint syndrome in the studied subgroups showed that individuals with RF+ACPA+ course of the disease with a statistically significant higher frequency had erosive radiological stages of the disease up to the development of bone ankylosis $\left(\chi^{2}=18.070 \mathrm{df}=6 \mathrm{p}=0.005\right)$ with pronounced deformity (Somers $d=0.300 p=0.008$ ) and impaired joint function of functional Classes 3 and 4 (Table 3 ).

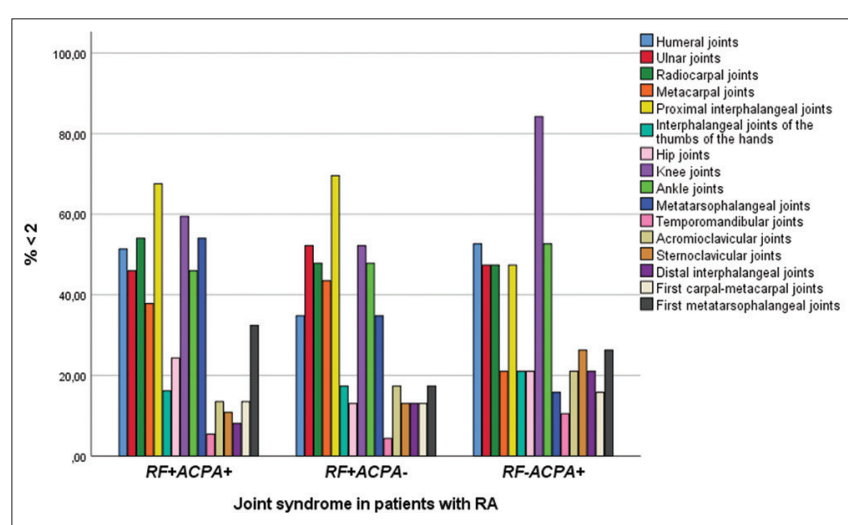

Figure 2: Joints involved in the pathological process in the studied subgroups

Further, the analysis of laboratory indicators of the inflammatory process activity was carried out, which revealed the presence of statistically significant differences in the study groups, which are shown in Figure 3.

Table 3: X-ray stage, functional status, and the presence of joint deformity in the studied subgroups

\begin{tabular}{|c|c|c|c|}
\hline \multirow[t]{2}{*}{ Variables } & $\mathrm{RF}+\mathrm{ACPA}+, \mathrm{n}=38$ & RF+ACPA-, $n=23$ & RF-ACPA,$+ n=20$ \\
\hline & \multicolumn{3}{|l|}{$\mathrm{N}(\%)$} \\
\hline X-ray Stage I & $6(15.8 \%)$ & $5(21.7 \%)$ & $7(35 \%)$ \\
\hline X-ray Stage II & $10(26.3 \%)$ & $12(52.2 \%)$ & $12(60 \%)$ \\
\hline X-ray Stage III & $12(31.6 \%)$ & $5(21.7 \%)$ & $1(5 \%)$ \\
\hline $\mathrm{X}$-ray Stage IV & $10(26.3 \%)$ & $1(4.4 \%)$ & 0 \\
\hline Functional status I & $7(18.4 \%)$ & $10(43.5 \%)$ & $6(30 \%)$ \\
\hline Functional status II & $23(60.5 \%)$ & $11(47.8 \%)$ & $14(70 \%)$ \\
\hline Functional status III & $7(18.4 \%)$ & $3(8.7 \%)$ & 0 \\
\hline Functional status IV & $1(2.7 \%)$ & 0 & 0 \\
\hline Presence of joint deformity & $23(60.5 \%)$ & $11(47.8 \%)$ & $5(25 \%)$ \\
\hline
\end{tabular}

Thus, it was found that in the RF+ACPA + subgroup of the course of the disease, the higher values of the level of CRP $(p=0.026)$ and alpha-1 globulins $(p=0.003)$ were observed, confirming the acute inflammatory process, which was also reflected in the direct correlation (Table 4) of the different strength of these indicators with the level of TJC, SJC, and VAS, duration of the course of RA and DAS 28 points.

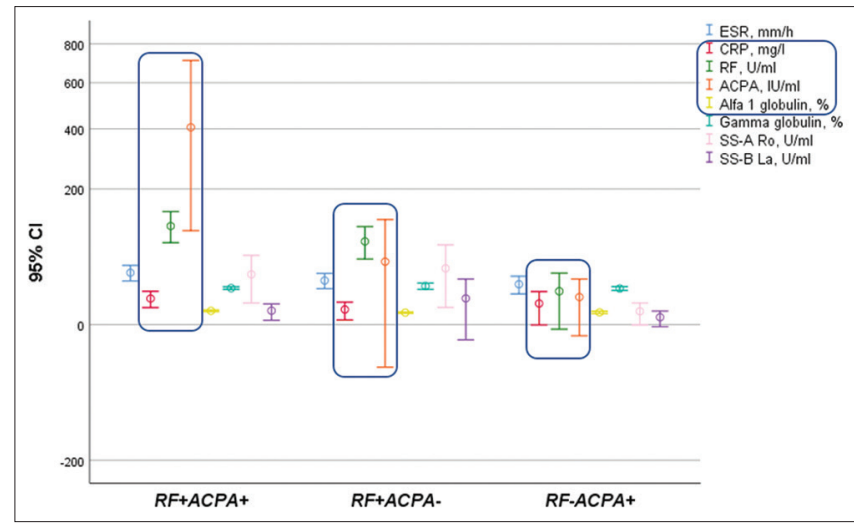

Figure 3: Comparative analysis of laboratory parameters

Correlation analysis in the RF+ ACPA- group showed a large association of disease activity with Table 4: Correlation analysis in the RF+ACPA+subgroup

\begin{tabular}{cccllll}
\hline RF+ ACPA+ & TJC & SJC & VAS by patient & VAS by doctor & RA duration & DAS 28 \\
\hline CRP, mg/l & & & & & & \\
$\rho$ & 0.561 & 0.559 & 0.385 & 0.459 & 0.447 & 0.748 \\
p & 0.000 & 0.000 & 0.020 & 0.005 & 0.006 & 0.000 \\
Alfa 1 globulin, \% & & & & & 0.552 \\
$\rho$ & 0.476 & 0.431 & 0.428 & & 0.001 \\
\hline p & 0.006 & 0.014 & 0.014 & & \\
\hline \multicolumn{7}{l}{ TJC: Tender joint count, SJC: Swollen joint count, VAS: Visually analog scale, CRP: C-reactive protein. }
\end{tabular}


markers of autoimmune inflammation-Gamma globulins, antibodies to Robert and Lane components (Table 5).

While in the group with a seronegative course of RA, relationships with disease triggers, such as the number of pregnancies and the duration of breastfeeding, were revealed, which confirm a more favorable course and late onset of RA among women with more pregnancies and longer duration of breastfeeding (Table 6).

Further, on the basis of the obtained results, a multinomial discriminant analysis was performed to predict such an endpoint as the stage of radiological damage to the joints. Quantitative variables were selected as independent factors, such as the age of the women studied at the time of examination, the age of disease onset, the duration of RA, SJC, TJC, the patient's and doctor's VAS, DAS 28 scores, the number of pregnancies and births, as well as the duration of breast-feeding in the anamnesis, as well as laboratory indicators of disease activity. As a result of the discriminant analysis performed using the step selection method, a discriminant model was obtained at step 2 (Figure 4), which is a system of equations (1) and (2):

$$
\begin{aligned}
& \mathrm{F} 1=-1,635+0,037^{*} \mathrm{X}_{\mathrm{CRP}}+0,144^{*} \mathrm{X}_{\mathrm{R} \text { Aduration }} \\
& \mathrm{F} 2=0,117+0,071^{*} \mathrm{X}_{\mathrm{CRP}}-0,078^{*} \mathrm{X}_{\text {RAduration }}
\end{aligned}
$$

where

$$
\begin{array}{ll}
\text { - } & \mathrm{F} 1 \text { - is the value of the discriminant function 1; } \\
\text { - } & \mathrm{F} 2 \text { - the value of the discriminant function 2; } \\
\mathrm{X}_{\mathrm{CRP}}-\mathrm{CRP}(\mathrm{mg} / \mathrm{l}) ; \\
\mathrm{X}_{\mathrm{RAduration}}-\text {-duration of RA (years) }
\end{array}
$$

Thus, the obtained discriminant model allows us to predict the stage of radiological damage of the joint calculating the coordinates of the functions F1 and F2 on the territorial map, where the predicted stage will be at the intersection of the $x$ and $y$ axes. The sensitivity of the obtained model (including after cross-checking) predicting the first radiological stage of RA was $71.6 \%$, Stage II-29.4\%, Stage III-37.5\%, and Stage IV-63.6\%.

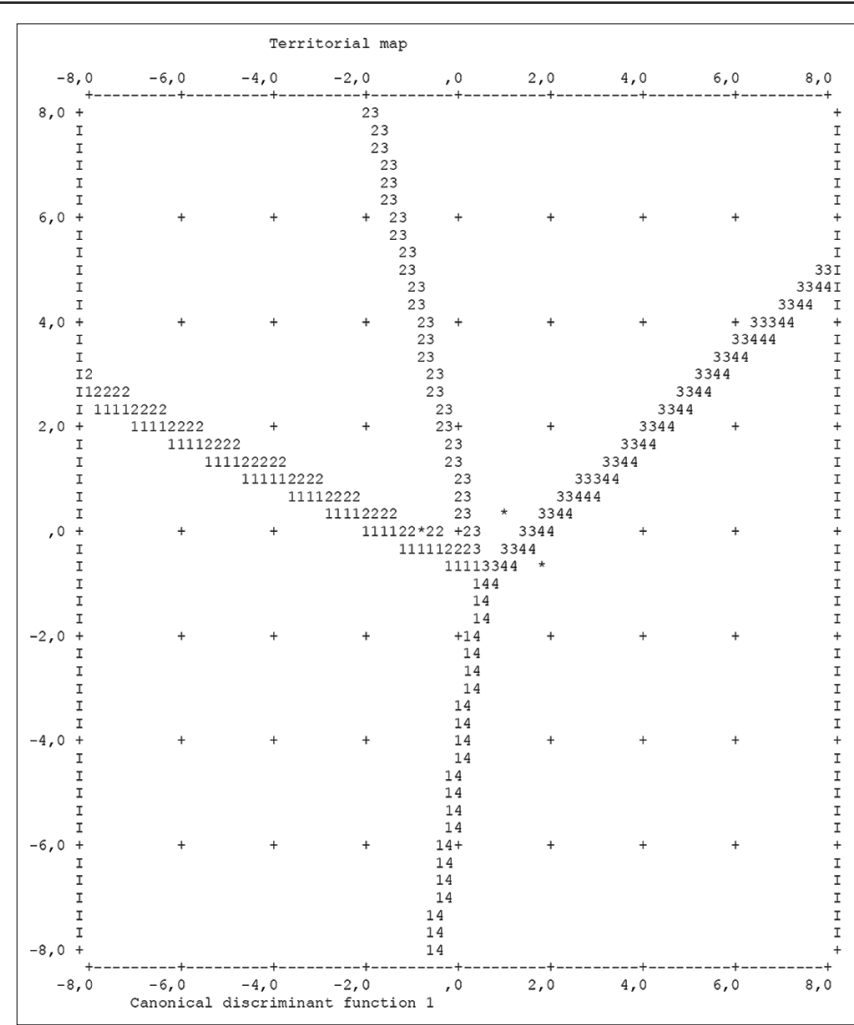

Figure 4: Territorial map of the multinomial discriminant analysis of the $X$-ray stage

\section{Discussion}

This is the first study of RA clinical course in Kazakhstan, which can be useful and supplement the data on the RA study in the world. In the group under the study, the RF+ACPA+ disease form prevailed, which is consistent with the data of many studies [1], [4], [19], [20], [21], [22]. The median age of disease onset was in the third decade of life, which also corresponds to the results of the majority of studies [4], [11], [23], [24], [25], [26], [27], [28], however, in Japan a later

\begin{tabular}{|c|c|c|c|c|c|c|c|c|}
\hline RF+ ACPA- & TJC & SJC & VAS by patient & VAS by doctor & RA duration & Age of RA debut & $\begin{array}{l}\text { Time from debut to } \\
\text { RA diagnosis }\end{array}$ & DAS 28 \\
\hline \multicolumn{9}{|l|}{$\mathrm{ESR}, \mathrm{mm} / \mathrm{h}$} \\
\hline$\rho$ & 0.437 & 0.447 & 0.416 & 0.429 & & & & 0.729 \\
\hline $\mathrm{p}$ & 0.037 & 0.033 & 0.048 & 0.041 & & & & 0.000 \\
\hline \multicolumn{9}{|c|}{ Gamma globulin, \% } \\
\hline$\rho$ & 0.635 & 0.527 & 0.532 & 0.545 & -0.478 & 0.633 & -0.410 & 0.666 \\
\hline $\mathrm{p}$ & 0.003 & 0.020 & 0.019 & 0.016 & 0.039 & 0.004 & 0.081 & 0.002 \\
\hline \multicolumn{9}{|l|}{ SS-A Ro } \\
\hline$\rho$ & 0.544 & 0.370 & 0.444 & 0.458 & & 0.590 & & 0.481 \\
\hline$p$ & 0.009 & 0.090 & 0.039 & 0.032 & & 0.004 & & 0.023 \\
\hline \multicolumn{9}{|l|}{ SS-B La } \\
\hline$\rho$ & 0.530 & 0.452 & & 0.501 & -0.436 & 0.455 & & 0.461 \\
\hline $\mathrm{p}$ & 0.011 & 0.035 & & 0.018 & 0.042 & 0.034 & & 0.031 \\
\hline
\end{tabular}
onset of RA was observed [29]. Studying the clinical picture of RA in our sample, the predominance of the articular form in all studied subgroups was found. Women with RF+ACPA+ course of the disease had a

Table 5: Correlation analysis in the RF+ACPA- subgroup 
Table 6: Correlation analysis in the RF- ACPA+subgroup

\begin{tabular}{lll}
\hline RF- ACPA+ & Age of RA debut & DAS 28 \\
\hline Number of pregnancies & & -0.434 \\
$\rho$ & & 0.056 \\
$p$ & & \\
Duration of breast-feeding & 0.549 & \\
$\rho$ & 0.015 & \\
$p$ & & \\
\hline
\end{tabular}

significantly higher incidence of late-stage disease and this subgroup also had erosive radiological stages of the disease up to the development of bone ankylosis with severe deformities and impaired joint function of functional Classes 3 and 4 with a statistically significant higher frequency, these data confirm a more severe course of RF+ ACPA+ RA form. These results support and supplement the data on a poorer prognosis of seropositive and ACPA-positive RA form [14], [30], [31], [32], [33]. It was found that in the $\mathrm{RF}+\mathrm{ACPA}+$ subgroup of the course of the disease, the higher values of the level of CRP $(p=0.026)$ and alpha-1 globulins $(p=0.003)$ were observed, which supports the above-mentioned data. The seropositive (RF+) ACPA- negative (ACPA-) subgroup of our study showed a large association of disease activity with markers of autoimmune inflammation, such as Gamma globulins, and antibodies to Robert and Lane components, which, in turn, also indicates a more severe course and a worse prognosis of RA in this group, particularly there should be alertness about Sjogren syndrome. The last mentioned results can be explained by the study of Hiwa et al., who came to the conclusion that RF-positive subset of ACPAnegative RA may convert to ACPA-positive form of the disease [34]. Studying the RA triggers, we have obtained the data, which indicates the more favorable course and late onset of RA among women with more pregnancies and longer duration of breastfeeding, which may be consistent with the data of number of authors, who studied protective role of the breastfeeding in RA development [35], [36], [37], [38]. Concerning the number of pregnancies Chen et al. did not find any relationship between the number of pregnancies and RA risk in their study [39]; however, Ren et al. indicated the strong relationship of the number of parity and decreased risk of RA [40]. The discriminant model, that allows to predict radiological damage using only two quite affordable parameters, may be applicable in RA patients' management.

\section{Conclusion}

The debut of the RA on average occurred in the third decade of the patients' life. The joint syndrome had a more unfavorable character in RF+ACPA+ patients' subgroup, however, RF+ACPA- subgroup also showed a predisposition to poorer prognosis. The obtained discriminant model may be useful for RA patients' management. Further studies on larger cohorts are needed to expand our obtained results.

\section{References}

1. Littlejohn EA, Monrad SU. Early diagnosis and treatment of rheumatoid arthritis. Prim Care. 2018;45(2):237-55. https://doi. org/10.1016/j.pop.2018.02.010

PMid:29759122

2. Silman AJ, Ollier W, Holligan S, Birrell F, Adebajo A, Asuzu MC et al. Absence of rheumatoid arthritis in a rural Nigerian population. J Rheumatol. 1993;20(4):618-22. PMid:8496853

3. Burton S, Lloyd M. An overview of rheumatoid arthritis. Nurs Stand. 2006;20(24):46-9. https://doi.org/10.7748/ ns2006.02.20.24.46.c4075

PMid: 16526162

4. Smolen JS, Aletaha D, Mclnnes IB. Rheumatoid arthritis. Lancet. 2016;388(10055):2023-38. https://doi.org/10.1016/ S0140-6736(16)30173-8

PMid:27156434

5. Silman AJ, Pearson JE. Epidemiology and genetics of rheumatoid arthritis. Arthritis Res. 2002;4(3):S265-72. https:// doi.org/10.1186/ar578

PMid:12110146

6. Kvien TK, Uhlig T, Ødegård S, Heiberg MS. Epidemiological aspects of rheumatoid arthritis: The sex ratio. Ann N Y Acad Sci. 2006;1069:212-22. https://doi.org/10.1196/annals.1351.019 PMid: 16855148

7. Naz SM, Symmons DP. Mortality in established rheumatoid arthritis. Best Pract Res Clin Rheumatol. 2007;21(5):871-83. https://doi.org/10.1016/j.berh.2007.05.003 PMid:17870033

8. Dadoun S, Zeboulon-Ktorza N, Combescure C, Elhai M, Rozenberg S, Gossec L, et al. Mortality in rheumatoid arthritis over the last fifty years: Systematic review and meta-analysis. Joint Bone Spine. 2013;80(1):29-33. https://doi.org/10.1016/j. jbspin.2012.02.005 PMid:22459416

9. Sokka T, Abelson B, Pincus T. Mortality in rheumatoid arthritis: 2008 update. Clin Exp Rheumatol. 2008;26(5):S35-61. PMid:19026144

10. Khurana R, Berney SM. Clinical aspects of rheumatoid arthritis. Pathophysiology. 2005;12(3):153-65. https://doi.org/10.1016/j. pathophys.2005.07.009 PMid:16125918

11. Scott DL, Wolfe F, Huizinga TW. Rheumatoid arthritis. Lancet. 2010;376(9746):1094-108. https://doi.org/10.1016/ S0140-6736(10)60826-4 PMid:20870100

12. Yousefghahari B, Alhooei S, Soleimani-Amiri MJ, Guran A Comparison of sensitivity and specificity of anti-CCP and antiMCV antibodies in an Iranian cohort of patients with rheumatoid arthritis. Caspian J Intern Med. 2013;4(3):702-6. PMid:24009964

13. Terao C, Ohmura K, Kochi $Y$, Ikari K, Okada Y, Shimizu M, et al. Anti-citrullinated peptide/protein antibody (ACPA)-negative RA shares a large proportion of susceptibility loci with ACPApositive RA: A meta-analysis of genome-wide association study in a Japanese population. Arthritis Res Ther. 2015;17(1):104. 
https://doi.org/10.1186/s13075-015-0623-4 PMid:25927497

14. van der Helm-van Mil AH, Verpoort KN, Breedveld FC, Toes RE, Huizinga TW. Antibodies to citrullinated proteins and differences in clinical progression of rheumatoid arthritis. Arthritis Res Ther. 2005;7(5):R949-58. https://doi.org/10.1186/ar1767

PMid:16207336

15. Nishimura K, Sugiyama D, Kogata $Y$, Tsuji G, Nakazawa $T$, Kawano S, et al. Meta-analysis: Diagnostic accuracy of anticyclic citrullinated peptide antibody and rheumatoid factor for rheumatoid arthritis. Ann Intern Med. 2007;146(11):797-808. https://doi.org/10.7326/0003-4819-146-11-200706050-00008 PMid:17548411

16. Rutherford A, Nikiphorou E, Galloway J. Rheumatoid arthritis. Lancet. 2010;376:1094-108. http://doi. org/10.1007/978-3-319-59963-2_3

17. Liao KP, Alfredsson L, Karlson EW. Environmental influences on risk for rheumatoid arthritis. Curr Opin Rheumatol. 2009;21(3):279-83. https://doi.org/10.1097/ BOR.0b013e32832a2e16

PMid: 19318947

18. Crowson CS, Matteson EL, Myasoedova E, Michet CJ, Ernste FC, Warrington $\mathrm{KJ}$, et al. The lifetime risk of adultonset rheumatoid arthritis and other inflammatory autoimmune rheumatic diseases. Arthritis Rheum. 2011;63(3):633-9. https:// doi.org/10.1002/art.30155

PMid:21360492

19. Grassi W, De Angelis R, Lamanna G, Cervini C. The clinical features of rheumatoid arthritis. Eur J Radiol. 1998;27(1):S1824. https://doi.org/10.1016/s0720-048x(98)00038-2 PMid:9652497

20. Lora V, Cerroni L, Cota C. Skin manifestations of rheumatoid arthritis. G Ital Dermatol Venereol. 2018;153(2):243-55. https:// doi.org/10.23736/S0392-0488.18.05872-8 PMid:29368864

21. Bajraktari $\mathrm{IH}$, Krasniqi B, Rexhepi S, Bexheti S, Bahtiri E, Bajraktari $\mathrm{H}$, et al. Prevalence of coxitis and its correlation with inflammatory activity in rheumatoid arthritis. Open Access Maced J Med Sci. 2018;6(2):336-9. https://doi.org/10.3889/ oamjms.2018.069

PMid:29531599

22. Aletaha D, Smolen JS. Diagnosis and management of rheumatoid arthritis: A review. JAMA. 2018;320(13):1360-72. https://doi.org/10.1001/jama.2018.13103 PMid:30285183

23. Lee DM, Weinblatt ME. Rheumatoid arthritis. Lancet. 2001;358(9285):903-11. https://doi.org/10.1016/ S0140-6736(01)06075-5

PMid:11567728

24. Wasserman AM. Diagnosis and management of rheumatoid arthritis. Am Fam Physician. 2011;84(11):1245-52. PMid:22150658

25. Traylor M, Knevel R, Cui J, Taylor J, Harm-Jan W, Conaghan PG, et al. Genetic associations with radiological damage in rheumatoid arthritis: Meta-analysis of seven genome-wide association studies of 2,775 cases. PLoS One. 2019;14(10):e0223246. https://doi.org/10.1371/journal. pone.0223246

PMid:31596875

26. van der Woude $\mathrm{D}$, van der Helm-van Mil AH. Update on the epidemiology, risk factors, and disease outcomes of rheumatoid arthritis. Best Pract Res Clin Rheumatol. 2018;32(2):174-87. https://doi.org/10.1016/j.berh.2018.10.005

PMid:30527425
27. Kojima M, Nakayama T, Tsutani K, Igarashi A, Kojima T, Suzuki S, et al. Epidemiological characteristics of rheumatoid arthritis in Japan: Prevalence estimates using a nationwide populationbased questionnaire survey. Mod Rheumatol. 2020;30(6):941-7. https://doi.org/10.1080/14397595.2019.1682776

PMid:31625435

28. Pashanova OV, Lopatina NB, Krivosheev SA, Baranova NY Comparative analysis of approaches and treatment results of patients with early and nonearly rheumatoid arthritis. Open Access Maced J Med Sci. 2019;7(17):2802-6. https://doi. org/10.3889/oamjms.2019.693

PMid:31844440

29. Kato E, Sawada T, Tahara K, Hayashi H, Tago M, Mori H, et al. The age at onset of rheumatoid arthritis is increasing in Japan: A nationwide database study. Int J Rheum Dis. 2017;20(7):839845. https://doi.org/10.1111/1756-185X.12998 PMid:28205423

30. Salma K, Nessrine A, Krystel E, Khaoula EK, Noura N, Khadija E, et al. Rheumatoid arthritis: Seropositivity versus seronegativity; a comparative cross-sectional study arising from Moroccan context. Curr Rheumatol Rev. 2020;16(2):143-8. https://doi.org/ $10.2174 / 1573397115666191018115337$ PMid:31656153

31. Choi S, Lee KH. Clinical management of seronegative and seropositive rheumatoid arthritis: A comparative study. PLoS One. 2018;13(4):e0195550. https://doi.org/10.1371/journal. pone. 0195550

PMid:29624625

32. Derksen VF, Huizinga TW, van der Woude D. The role of autoantibodies in the pathophysiology of rheumatoid arthritis. Semin Immunopathol. 2017;39(4):437-46. https://doi. org/10.1007/s00281-017-0627-z

PMid:28451788

33. Scherer HU, Häupl T, Burmester GR. The etiology of rheumatoid arthritis. J Autoimmun. 2020;110:102400. https:// doi.org/10.1016/j.jaut.2019.102400

PMid:31980337

34. Hiwa R, Ohmura K, Nakabo S, Terao C, Murakami K, Nakashima R, et al. Only rheumatoid factor-positive subset of anti-citrullinated peptide/protein antibody-negative rheumatoid arthritis may seroconvert to anti-citrullinated peptide/protein antibody-positive. Int J Rheum Dis. 2017;20(6):731-6. https:// doi.org/10.1111/1756-185X.13000

PMid:28198158

35. Chen H, Wang J, Zhou W, Yin H, Wang M. Breastfeeding and risk of rheumatoid arthritis: A systematic review and metaanalysis. J Rheumatol. 2015;42(9):1563-9. https://doi.org/10.3899/ jrheum.150195 PMid:26178286

36. Karlson EW, Mandl LA, Hankinson SE, Grodstein F. Do breastfeeding and other reproductive factors influence future risk of rheumatoid arthritis? Results from the nurses' health study. Arthritis Rheum. 2004;50(11):3458-67. https://doi.org/10.1002/ art.20621

PMid:15529351

37. Adab $\mathrm{P}$, Jiang CQ, Rankin E, Tsang YW, Lam TH, Barlow J, et al. Breastfeeding practice, oral contraceptive use and risk of rheumatoid arthritis among Chinese women: The Guangzhou Biobank cohort study. Rheumatology (Oxford). 2014;53(5):8606. https://doi.org/10.1093/rheumatology/ket456 PMid:24395920

38. Lahiri M, Luben RN, Morgan C, Bunn DK, Marshall T, Lunt $M$, et al. Using lifestyle factors to identify individuals at higher risk of inflammatory polyarthritis (results from the European prospective investigation of cancer-Norfolk and 
the Norfolk arthritis register--the EPIC-2-NOAR study). Ann Rheum Dis. 2014;73(1):219-26. https://doi.org/10.1136/ annrheumdis-2012-202481

PMid:23505230

39. Chen WM, Subesinghe S, Muller S, Hider SL, Mallen CD, Scott IC. The association between gravidity, parity and the risk of developing rheumatoid arthritis: A systematic review and meta-analysis. Semin Arthritis Rheum. 2020;50(2):252-60. https://doi.org/10.1016/j.semarthrit.2019.09.003

PMid:31530401

40. Ren L, Guo P, Sun QM, Liu H, Chen Y, Huang Y, et al. Number of parity and the risk of rheumatoid arthritis in women: A doseresponse meta-analysis of observational studies. J Obstet Gynaecol Res. 2017;43(9):1428-40. https://doi.org/10.1111/ jog. 13370

PMid:28613016 